\title{
Two year persistent treatment effect in reducing nasal symptoms of cat allergy after 4 doses of Cat-PAD, the first in a new class of synthetic peptide immuno-regulatory epitopes
}

\author{
Roderick Hafner ${ }^{1 *}$, Peter Couroux ${ }^{2}$, Kristen Armstrong ${ }^{3}$, Deepen Patel ${ }^{4}$, Mark Larche ${ }^{5}$, Brett Haumann ${ }^{1}$
}

From 9th Symposium of Experimental Rhinology and Immunology of the Nose (SERIN 2013)

Leuven, Belgium. 21-23 March 2013

\section{Background}

Treatment with Cat-PAD (also known as ToleroMune ${ }^{\circledR}$ Cat, the first in a new class of synthetic peptide immuno-regulatory epitopes), in an Environmental Exposure Chamber (EEC) model of cat allergy showed a persistent treatment effect one year [1] and two years [2] after administration of only 4 injections over 12 weeks. Here we report the differences in Total Nasal Symptom Scores (TNSS) between Cat-PAD treatment arms and placebo two years after treatment started.

\section{Method}

Originally 202 subjects were randomised to $4 \times 6 \mathrm{nmol}$ Cat-PAD 4 weeks (wk) apart, $8 \times 3 \mathrm{nmol}$ Cat-PAD 2wk apart, or placebo. EEC challenges were performed at baseline and $18-22 \mathrm{wk} .89$ subjects were recruited into a follow-on study one year after the start of treatment. Of the subjects who completed the one year EEC challenge, 50 subjects were recruited for a further EEC challenge 100-104wk after the start of treatment. All EEC challenges consisted of 4 consecutive days of 3 hours (h) of allergen exposure with Fel d1 levels of circa $50 \mathrm{ng} / \mathrm{m} 3$. The 4 day challenge was designed to ensure late phase responses were present in the nasal airway. Subjects scored each of 4 symptoms (Running nose; Sneezing; Blocked nose; Itchy nose) on a scale of $0-3$ every $30 \mathrm{~min}$ utes during the EEC challenge. These scores were summed to give a TNSS on a scale of 0-12.

\section{Results}

The least squares (LS) mean TNSS was significantly lower ( $\mathrm{p}<0.05)$ for $4 \times 6 \mathrm{nmol}$ Cat-PAD vs placebo at the following EEC challenge: Day 1 at $2 \mathrm{~h}$ and 2.5h; Day 2 at $2 \mathrm{~h}, 2.5 \mathrm{~h}$ and 3h; Day 3 at 1h, 1.5h, 2h, 2.5h and 3h. On Day 4 of EEC Challenge, when the cumulative allergen challenge is greatest and late phase responses in the nose are likely to be maximal, LS mean TNSS was significantly lower for $4 \times 6 \mathrm{nmol}$ Cat-PAD vs placebo at $2 \mathrm{~h}(4.818$ vs 7.762 , $\mathrm{p}=0.0090)$, 2.5h (5.091 vs 7.667, $\mathrm{p}=0.0290)$ and $3 \mathrm{~h}(4.818$ vs 7.952, $\mathrm{p}=0.0080)$ time points. No significant reductions in LS mean TNSS were observed for $8 \mathrm{x} 3 \mathrm{nmol}$ Cat-PAD vs placebo.

\section{Conclusion}

Treatment with 4 injections of $6 \mathrm{nmol}$ Cat-PAD over 12 wk showed a substantial reduction in patients' TNSS that persisted two years after starting treatment. The treatment effect is substantial under conditions where late phase responses are expected to be present in the nasal airway. Cat-PAD is the first in a new class of synthetic peptide immuno-regulatory epitopes and may confer long-term disease-modification in chronic nasal airway disease due to cat allergy.

\section{Author details}

${ }^{1}$ Circassia Ltd, R\&D, Oxford, UK. ${ }^{2}$ Cetero Research, R\&D, Missisauga, Canada. ${ }^{3}$ Adiga, Life Sciences, Hamilton, Canada. ${ }^{4}$ Cetero Research, R\&D, Toronto, Canada. ${ }^{5}$ McMaster University, Department of Medicine, Hamilton, Canada.

Published: 16 July 2013

${ }^{1}$ Circassia Ltd, R\&D, Oxford, UK

Full list of author information is available at the end of the article

(0) 2013 Hafner et al; licensee BioMed Central Ltd. This is an Open Access article distributed under the terms of the Creative Commons Attribution License (http://creativecommons.org/licenses/by/2.0), which permits unrestricted use, distribution, and reproduction in any medium, provided the original work is properly cited. 


\section{References}

1. Patel, et al: JACl 2013.

2. Hafner, et al: $A A A A l 2013$

doi:10.1186/2045-7022-3-S2-O7

Cite this article as: Hafner et al:: Two year persistent treatment effect in reducing nasal symptoms of cat allergy after 4 doses of Cat-PAD, the first in a new class of synthetic peptide immuno-regulatory epitopes. Clinical and Translational Allergy 2013 3(Suppl 2):07.

Submit your next manuscript to BioMed Central and take full advantage of:

- Convenient online submission

- Thorough peer review

- No space constraints or color figure charges

- Immediate publication on acceptance

- Inclusion in PubMed, CAS, Scopus and Google Scholar

- Research which is freely available for redistribution

Submit your manuscript at www.biomedcentral.com/submit
Ciomed Central 